\title{
DETERMINATION OF THE TOLERANT CONCENTRATION OF EISENIA FETIDA TO CHROME SOLID RESIDUES FROM TANNERY
}

\author{
Robert BULEJE DEL CARPIO*, Liliana MARRUFO SALDAÑA* \\ Productive Innovation and Technological Transfer Center of Leather, Footwear and related industries (CITEccal Lima). \\ Technological Institute of Production (ITP), Caquetá Ave. 1300, Rímac, 15094, Lima, Perú, rbuleje@itp.gob.pe, \\ Imarrufo@itp.gob.pe
}

DETERMINATION OF THE TOLERANT CONCENTRATION OF Eisenia fetida TO CHROME SOLID RESIDUES FROM TANNERY ABSTRACT. The tanning industry, although it is characterized by the use of the skin waste originated by the cattle raising, in contrast, produces huge volumes of waste, among which chrome shavings stand out due to their high percentage of chromium. The objective of this research was to determine the concentration where earthworms (Eisenia fetida) could tolerate chrome shavings, in order to evaluate the potential for degradation of these wastes through biological treatment. To determine the tolerant concentration, an experimental design was established that included as factors, the time of exposure in weeks (0-11) and the concentrations of exposure: $0.01,0.02,0.04,0.08,0.12$ and 0.16 grams of shavings per grams of substrate. The response variable was the mortality rate. Each treatment was performed in triplicate and a negative control was included. Statistical treatment was performed using ANOVA and multiple comparison tests at $95 \%$ confidence with the statistical complement Real Statistics, Statgraphics and Yupana software. The tolerant concentration established in the study was $0.04 \mathrm{~g} / \mathrm{g}$ (grams of shavings per grams of substrate) which is equivalent to $636 \mathrm{mg} / \mathrm{kg}$ (based on dry weight) expressed in weight of chrome per weight of compost.

KEY WORDS: chromium, chrome shavings, Eisenia fetida, bioassay

\section{DETERMINAREA CONCENTRAȚIEI DE REZIDUURI SOLIDE DE CROM DIN TĂBĂCĂRIE TOLERATE DE Eisenia fetida ÎN VEDEREA DEGRADĂRII ACESTORA}

REZUMAT. Industria de pielărie, deși se caracterizează prin utilizarea deșeurilor de piele provenite de la creșterea bovinelor, produce, în schimb, volume imense de deșeuri, dintre care se remarcă răzătura de piele cromată datorită procentului ridicat de crom. Obiectivul acestei cercetări a fost de a determina concentrația în care râmele (Eisenia fetida) ar putea tolera răzătura de piele cromată, pentru a evalua potențialul de degradare a acestor deșeuri prin tratament biologic. Pentru a determina concentrația tolerată, s-a conceput un experiment care a inclus ca factori timpul de expunere în săptămâni (0-11) și concentrațiile de expunere: $0,01,0,02,0,04,0,08,0,12$ și 0,16 grame de răzătură per grame de substrat. Variabila de răspuns a fost rata mortalității. Fiecare tratament a fost efectuat de trei ori și a fost inclus un martor negativ. Analiza statistică a fost efectuată utilizând testul ANOVA și teste de comparație multiple la un nivel de încredere de $95 \%$ folosind programele complementare de analiză statistică Real Statistics, Statgraphics și Yupana. Concentrația tolerată stabilită în studiu a fost de 0,04 g/g (grame de răzătură de piele cromată per grame de substrat), care este echivalentă cu $636 \mathrm{mg} / \mathrm{kg}$ (pe baza greutății substanței uscate) exprimată în greutate crom per greutate compost.

CUVINTE CHEIE: crom, răzătură de piele cromată, Eisenia fetida, bioanaliză

\section{DÉTERMINATION DE LA CONCENTRATION DE RÉSIDUS SOLIDES DE CHROME TOLÉRÉE PAR Eisenia fetida POUR LA DÉGRADATION DE CES DÉCHETS}

RÉSUMÉ. L'industrie du cuir, bien que caractérisée par l'utilisation de déchets de cuir provenant de l'élevage du bétail, produit à la place d'énormes volumes de déchets, dont les copeaux de cuir chromé sont perceptibles en raison du pourcentage élevé de chrome. Le but de cette recherche était de déterminer la concentration dans laquelle les vers de terre (Eisenia fetida) pouvaient tolérer les copeaux de cuir chromé, d'évaluer le potentiel de dégradation de ces déchets par traitement biologique. Pour déterminer la concentration de tolérance, une expérience a été conçue qui incluait comme facteurs le temps d'exposition en semaines (0-11) et les concentrations d'exposition : 0,01, 0,02, $0,04,0,08,0,12$ et 0,16 gramme de copeaux par gramme de substrat. La variable de réponse était le taux de mortalité. Chaque traitement a été effectué trois fois et un contrôle négatif a été inclus. L'analyse statistique a été réalisée en utilisant le teste ANOVA et des tests de comparaison multiples à un niveau de confiance de $95 \%$ en utilisant les programmes d'analyse statistique complémentaires comme Real Statistics, Statgraphics et Yupana. La concentration de tolérance établie dans l'étude était de $0,04 \mathrm{~g} / \mathrm{g}$ (grammes de copeaux de cuir chromé par gramme de substrat), ce qui équivaut à $636 \mathrm{mg} / \mathrm{kg}$ (sur la base du poids de la matière sèche) exprimée en poids de chrome par poids de compost.

MOTS CLÉS : chrome, copeaux de cuir chromé, Eisenia fetida, essai biologique

\footnotetext{
* Correspondence to: Liliana MARRUFO SALDAÑA and Robert BULEJE DEL CARPIO, Productive Innovation and Technological Transfer Center of Leather, Footwear and related industries (CITEccal Lima). Technological Institute of Production (ITP), Caquetá Ave. 1300, Rímac, 15094, Lima, Perú,Imarrufo@itp.gob.pe, rbuleje@itp.gob.pe
} 


\section{INTRODUCTION}

Tanning industry is a manufacturing activity, which, together with the footwear and related industries, is important due to the employability it generates and the use it makes of the skin waste originating from livestock farming. However, due to the complexity of its processes and the chemical products used, it produces large volumes of solid waste and effluents with a high pollution load. Among the solid waste generated, the large volumes of wet blue chrome shavings, solid waste generated in the trimming process. Wet blue leather is characterized by its high chromium content, acquired after the leather passes through the tanning stage, which could compromise environmental and human health [1].

For each ton of leather produced, 200 to $250 \mathrm{~kg}$ of tanned solid waste would be generated [2]. These waste products occupy important spaces in the industries, giving rise to an idle installed capacity and whose final disposal is not necessarily adequate. The danger of these wastes lies mainly in their chromium content, which comes from the basic salts of this metal, which is the most widely, used and diffused tanning agent, as it makes the leather imputrescible, durable and resistant, characteristics that no other tannery agent has managed to match.

Chromium is naturally present in the earth's crust, however, high concentrations of it can be attributed to the wastewater discharges generated in the metallurgical industry and tanneries [3], is also a trace element, a metal that is important for the metabolism of living beings, however, at high concentrations [4], such as those found in chrome shavings, it becomes a hazard due to the toxicity generated by its +3 and +6 species. Although the +3 species is more stable and less toxic, it has been shown that under oxidative conditions it is susceptible to conversion to $\mathrm{Cr}+6$. This species has been classified as carcinogenic [5]. Traditionally, this waste has been disposed of in an inappropriate manner in landfills or outdoors, however, with the emergence of environmental regulations worldwide, the rigour of disposal has increased. Some are disposed of as low-cost non-hazardous waste and others as high-cost hazardous waste. For this reason, companies have chosen to reduce the amount of solid waste generated as far as possible, and with the rest, they have opted for ways of recovering it (taking advantage of collagen) and treating it to reduce its dangerousness and, consequently, its cost of disposal $[6,7]$.

Among the treatment alternatives, the biological pathway always stands out, due to its low installation and operation costs, even reaching comparable results with the physical-chemical methods, the space they require being its only limitation. However, systematic information regarding the use of earthworms to treat these wastes and their interaction with chrome is limited $[3,8,9]$. The aim of this research work was to determine the tolerant concentration of Eisenia fetida to chrome shavings, which is the starting point for evaluating the potential for degradation of these wastes through biological treatment.

\section{EXPERIMENTAL}

This research was developed in the facilities of the Productive Innovation and Technological Transfer Center of Leather, Footwear and related industries (CITEccal Lima).

\section{Materials and Methods}

\section{Earthworms}

The earthworms ( $E$. fetida) were acquired from the National Agrarian University La Molina (UNALM), Lima, Peru, and were selected earthworms with visible clitellum, the presence of which indicates that the earthworms are sexually mature. This was done in order to have a homogeneous population for testing $[10,11]$.

Before any test was carried out on the earthworms, the harmlessness of the new support medium (mature compost) was verified by means of a survival test. This test consisted of placing 20 earthworms on a portion of the new medium and waiting for them to be introduced into it, otherwise the medium was declared uninhabitable. Once the safety was 
verified, a container with the new medium was conditioned to contain all the earthworms used in the investigation. The humidity of the medium was controlled moisture $80-85 \%$ at all times [12].

\section{Chrome Shavings}

Chrome shavings were collected from a tannery that processes bovine skin, located in the district of San Juan de Lurigancho, Lima, Peru.

\section{Experimental Design}

In order to observe the behaviour and mobility of earthworms in the face of moderate exposure to shavings, a preliminary experiment was designed with 6 grams of shavings, 150 grams of soil and 250 grams of compost resulting in a concentration of 0.015 grams of shavings per gram of substrate. The shavings, soil and compost were systematically distributed as shown in Table 1. Only in the first container were the three substrates mixed. All containers were inoculated with 10 earthworms.

The total exposure time was set at four days. A daily review was conducted to check the toxic effect of the shavings on the earthworms; however, no mortality was reported in any container. For the following tests, the distribution by mixture (Box 1, Table 1) was established as it offers the greatest interaction between the shavings and the earthworms and the distribution by layer (Box 3, Table 1) was established as it offers the least interaction possible between the earthworms and the shavings.

Table 1: Experimental design, exposure to different distributions

\begin{tabular}{cl}
\hline Box & \multicolumn{1}{c}{ Distribution } \\
\hline 1 & Total mix of the substrate \\
2 & Stratum 1: a mixture of $75 \mathrm{~g}$ of soil and $125 \mathrm{~g}$ of compost \\
& Stratum 2: a mixture of $75 \mathrm{~g}$ of soil, $125 \mathrm{~g}$ of compost and $6 \mathrm{~g}$ of chrome shavings \\
3 & Stratum $1^{\circ}:$ mix $150 \mathrm{~g}$ of soil and $250 \mathrm{~g}$ of compost. \\
& Stratum 2: $6 \mathrm{~g}$ of chrome shavings \\
4 & Stratum $1^{\circ}:$ mix $50 \mathrm{~g}$ of soil, $50 \mathrm{~g}$ of compost and $1 \mathrm{~g}$ of chrome shavings \\
& Stratum 2: $50 \mathrm{~g}$ of soil, $100 \mathrm{~g}$ of compost and $2 \mathrm{~g}$ of chrome shavings \\
& Stratum 3: $50 \mathrm{~g}$ of soil, $100 \mathrm{~g}$ of compost and $3 \mathrm{~g}$ of chrome shavings
\end{tabular}

In order to determine a threshold concentration for exposure of earthworms to shavings, a preliminary experimental exposure design was established, where exposure concentrations were $0.075,0.100,0.150$ and 0.200 grams of shavings per gram of substrate in mixture distribution (Table 2).
Test was conducted in individual containers with 10 earthworms per concentration. Identical substrates were used. The total exposure time was established to 4 days, in constant monitoring of the activity of the earthworms and the visible effects of the shavings on them.

Table 2: Experimental design, preliminary exposure to different concentrations

\begin{tabular}{ccccc}
\hline Box & $\begin{array}{c}\text { Soil } \\
(\mathrm{g})\end{array}$ & $\begin{array}{c}\text { Compost } \\
(\mathrm{g})\end{array}$ & $\begin{array}{c}\text { Chrome } \\
\text { shavings }(\mathrm{g})\end{array}$ & $\begin{array}{c}\text { Concentration (g of chrome } \\
\text { shavings/g of substrate) }\end{array}$ \\
\hline 1 & 100 & 300 & 30 & 0.075 \\
2 & 100 & 200 & 30 & 0.100 \\
3 & 100 & 100 & 30 & 0.150 \\
4 & 100 & 50 & 30 & 0.200 \\
\hline
\end{tabular}

From the observation of the behavior of the earthworms (permanence or not in the substrate) a maximum viable concentration of exposure equal to 0.16 grams of chrome shavings per grams of substrate was established, from which the concentrations of the experimental design of exposure in decreasing geometric progression were determined, such concentrations were: $0.01,0.02,0.04,0.08,0.12$ and 0.16 grams of chrome shavings per grams of substrate (Table 3 ) $[10,11]$. These concentrations were made at the humidity of each component, and then the mixture was taken to $80-85 \%$ moisture (dry basis). 
As mentioned above, it was decided on two configurations in the distribution of the substrates. It started with the distribution by layers (mixed substrate covered with shavings), however, when it was verified that the earthworms did not have apparent contact with the shavings, a mixture of the substrates was made, to guarantee the interaction of the earthworms with the chrome shavings. This mixing was done after 7 (D-7), 14 (D-14) and 28 (D-28) days of the earthworms' stay in the stratified substrate.

A chronic exposure period (greater than 28 days) was established for this experiment, no additional food was added during testing. A weekly moisture control was performed to verify its value within the optimal range (80-85\%) [13]. Each container was inoculated with 20 sexually mature earthworms. To control the quality of the test, a negative control (substrate without the presence of chrome shavings) was carried out in parallel for each group evaluated (D-7, D-14 and D-28), and each concentration and negative control was carried out in triplicate. The quality control to validate the data was set to obtain a survival above $90 \%$ in the negative controls [10, 11].

The number of earthworms in the containers was counted weekly. The counts were done in an enclosed area with limited natural light to minimize stress on the earthworms.

Statistical treatment to analyze significant differences between the data groups (response variable: mortality) was performed using the multifactorial ANOVA test and Tukey multiple comparisons with the statistical complement Real Statistics and the Statgraphics and Yupana software. Tests were performed at $95 \%$ confidence.

Table 3: Experimental design, systematic evaluation of earthworm exposure to shavings

\begin{tabular}{ccccc}
\hline $\begin{array}{c}\text { Name of the } \\
\text { concentration }\end{array}$ & Soil (g) & $\begin{array}{c}\text { Compost } \\
\text { (g) }\end{array}$ & $\begin{array}{c}\text { Chrome } \\
\text { shavings (g) }\end{array}$ & $\begin{array}{c}\text { Concentration } \\
\text { (g of chrome shavings/g } \\
\text { of substrate) }\end{array}$ \\
\hline C-01 & 75 & 300 & 3.8 & 0.01 \\
C-02 & 75 & 300 & 7.5 & 0.02 \\
C-04 & 75 & 300 & 15.0 & 0.04 \\
C-08 & 75 & 300 & 30.0 & 0.08 \\
C-12 & 75 & 300 & 45.0 & 0.12 \\
C-16 & 75 & 300 & 60.0 & 0.16 \\
C-00 (white) & 75 & 300 & 0 & 0.00 \\
Moisture (dry basis) & $0 \%$ & $33.4 \%$ & $25.5 \%$ & \\
\hline
\end{tabular}

\section{RESULTS AND DISCUSSIONS}

\section{Preliminary Study}

The survival of negative controls was above $90 \%$, therefore the quality control required for this type of trial was found. The results obtained, shown in Figure 1, indicate that in the samples coming from the previous exposure to 7 days per stratum (D-7), the concentrations 0.12 $\mathrm{g} / \mathrm{g}$ and $0.16 \mathrm{~g} / \mathrm{g}$ cause the total death of the earthworms from week 1 , on the other hand, the concentration $0.08 \mathrm{~g} / \mathrm{g}$ exerts the gradual increase of the mortality through the weeks. The samples with previous exposure of 14 days (D-14) (Figure 2) and 28 days (D-28) (Figure 3 ) showed a similar behavior to the previous group, however, the concentrations $0.12 \mathrm{~g} / \mathrm{g}$ and $0.16 \mathrm{~g} / \mathrm{g}$ began to cause total mortality from the fifth and second week respectively, which would indicate that previous exposure to the environment is a factor that influences the response of the earthworms, because the earthworms are sensitive to changes in the environment. For this reason, the guidelines recommend a minimum adaptation time to the test substrate or living environment [10].

Statistical analysis with multifactorial ANOVA in Statgraphics software, at 95\% confidence, to evaluate the contribution of the previous exposure time factor, indicated that there were no significant differences between groups D-14 and D-28, unlike D-7 which did present significant differences with the mentioned groups.

In negative control and the concentrations $0.01 \mathrm{~g} / \mathrm{g}, 0.02 \mathrm{~g} / \mathrm{g}$ and $0.04 \mathrm{~g} / \mathrm{g}$ the mortality 
was maintained at the same level during all the weeks, in the same way, no significant differences existed between these treatments and between the groups of previous exposure (D-7, D-14 and D-28), which was established by means of comparisons Tukey at $95 \%$ confidence. This behavior led to estimate that the tolerant concentration, which causes no effect on earthworms (NOEC), is around $0.04 \mathrm{~g} / \mathrm{g}$.
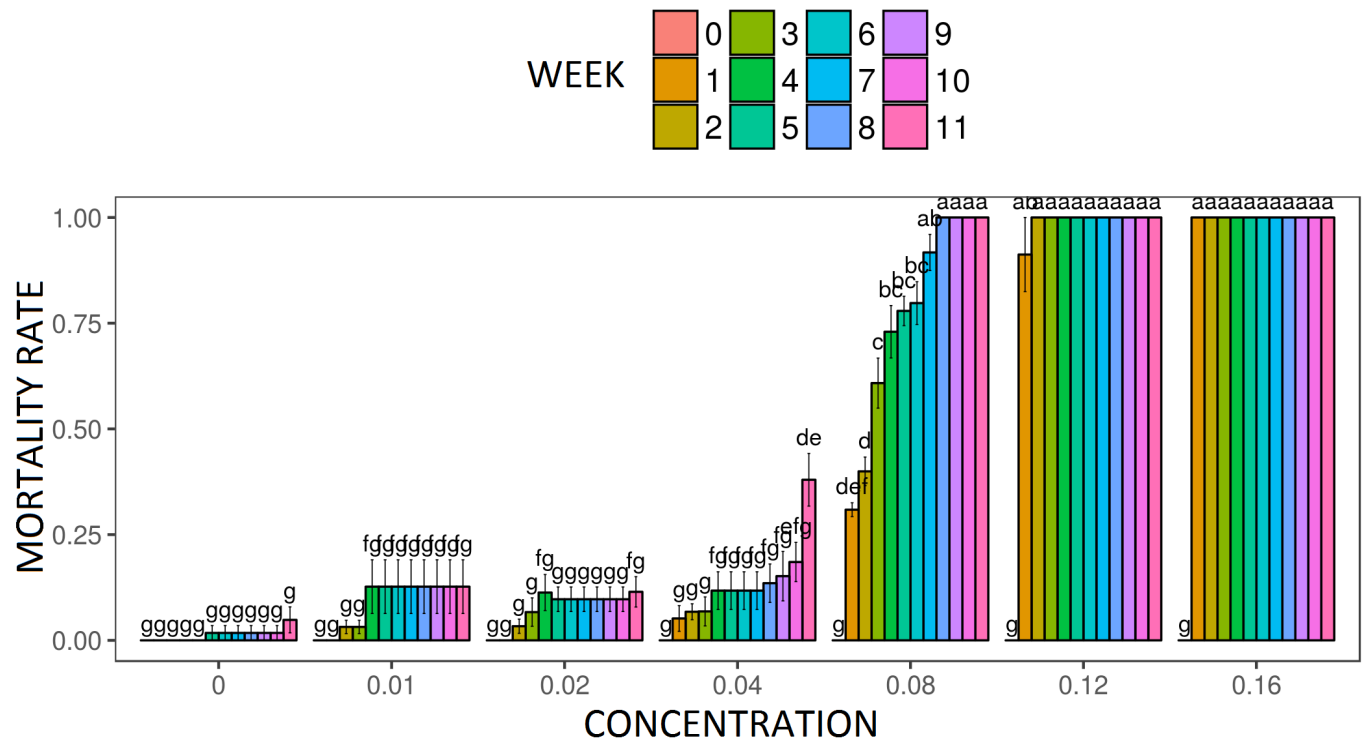

Figure 1. Answers from Group D-7

WEEK
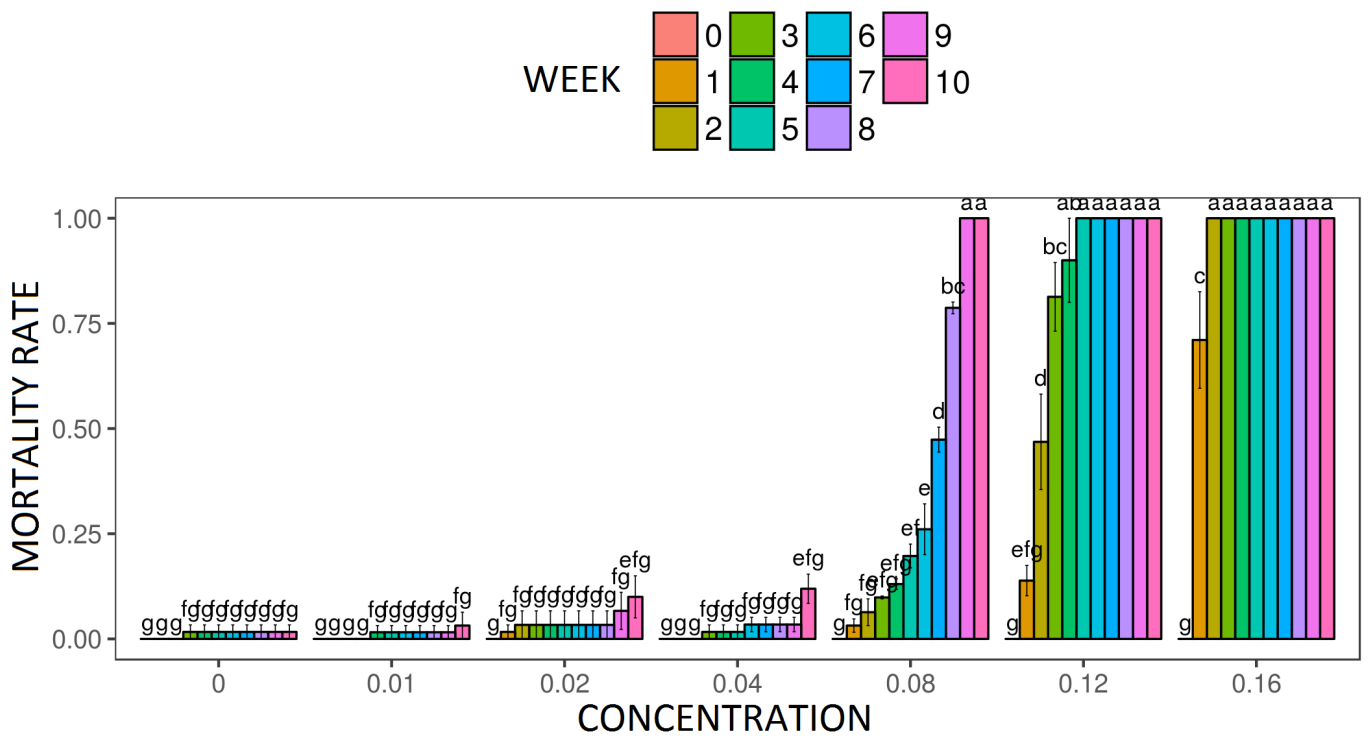

Figure 2. Answers from Group D-14 

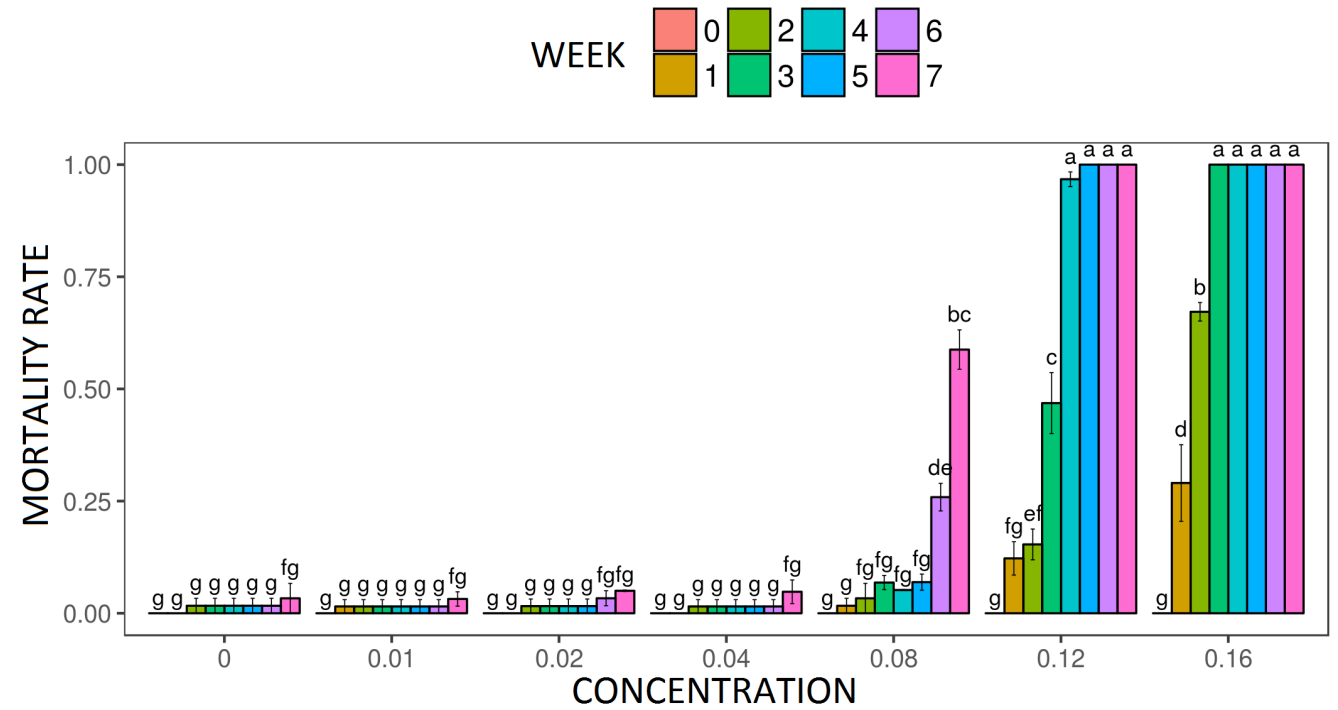

Figure 3. Answers from Group D-28

Chrome shavings have an average chromium concentration near to $16323.73 \mathrm{mg} / \mathrm{kg}$ on dry weight [14], therefore, the concentration of $0.04 \mathrm{~g} / \mathrm{g}$ would be equivalent to $636 \mathrm{mg} / \mathrm{kg}$ expressed in weight of chromium per weight of substrate, a concentration lower than the range determined by Sivakumar and Subbhuraam [3] as average lethal concentration (LC5014days) ranging from $1656 \mathrm{mg} / \mathrm{kg}$ to $1902 \mathrm{mg} /$ $\mathrm{kg}$ in different types of soil and organic matter, which supports the tolerant concentration (NOEC) determined in this research. However, it disagrees with the value reported by Lock and Janssen [8], where no mortality of Eisenia fetida is recorded at a concentration of 1800 $\mathrm{mg} / \mathrm{kg}$ of chromium (dry basis) per substrate (developed according to OECD guidelines), this suggests that organic matter present in the substrate may have increased the toxicity of chromium on earthworms. It should also be borne in mind that chromium in the shavings is encapsulated, and although it is considered to be the problem element in the investigation, it is not the only agent that could be exerting toxicity on earthworms.

The survival of the earthworms to long periods (chronic exposure), without any food, suggests that the earthworms have taken advantage of the collagen present in the shavings, being the route of entry of the chromium the oral route, in contrast, the concentrations $\mathrm{C}-12$ and $\mathrm{C}-16$, suggest the toxic effect through the skin of the earthworms, since it was found in the containers to the first and second week (acute exposure), dead individuals, sectioned and/or decomposed [15].

During the counts, the presence of cocoon up to tolerant concentration was reported, including the presence of some developed juveniles, due to the length of the test. However, values close to the tolerant concentration showed a decreasing trend in the presence of cocoons $[8,9]$.

\section{CONCLUSIONS}

This study established as tolerant concentration $0.04 \mathrm{~g} / \mathrm{g}$ (grams of chrome shavings per grams of substrate), which was the highest concentration that caused no effect on the earthworm population and did not compromise their survival over time. The substrates and the shavings provided the necessary food for the survival of the earthworms.

This tolerant concentration corresponds to a chrome concentration of approximately $636 \mathrm{mg} / \mathrm{kg}$ (dry basis). The previous time of adaptation to the environment is an important factor to consider in studies of chrome removal from chrome shavings using earthworms. Ensuring the survival and development of earthworms within shaved media is vital for 
future bioaccumulation studies and evaluation of potential uses of chrome shavings compost.

\section{Acknowledgements}

We acknowledge to the Productive Innovation and Technological Transfer Center of Leather, Footwear and related industries (CITEccal Lima) and all its staff for the support provided to carry out this project.

\section{REFERENCES}

1. Chowdhury, M., Mostafa, M.G., Biswas, T.K., Saha, A.K., Treatment of leather industrial effluents by filtration and coagulation processes, Water Resour Ind, 2013, 3, 11-22, https://doi.org/10.1016/j. wri.2013.05.002.

2. Mella, B., Glanert, A.C., Gutterres, M., Removal of chromium from tanning wastewater and its reuse, Process Saf Environ Prot, 2015, 95, 195-201, https:// doi.org/10.1016/j.psep.2015.03.007.

3. Sivakumar, S., Subbhuraam, C.V., Toxicity of chromium(III) and chromium(VI) to the earthworm Eisenia fetida, Ecotoxicol Environ Saf, 2005, 62, 1, 93-8, https://doi. org/10.1016/j.ecoenv.2004.08.006.

4. Singh, H.P., Mahajan, P., Kaur, S., Batish, D.R., Kohli, R.K., Chromium toxicity and tolerance in plants, Environ Chem Lett, 2013, 11, 3, 229-54, https://doi. org/10.1007/s10311-013-0407-5.

5. Domènech, X., Fundamentos de química Ambiental, Madrid: Editorial Sintesis, 2014.

6. Bautista, M.E., Pérez, L., García, M.T., Cuadros, S., Marsal, A., Valorization of tannery wastes: Lipoamino acid surfactant mixtures from the protein fraction of process wastewater, Chem Eng J, 2015, 262, 399-408, https://doi.org/10.1016/j. cej.2014.10.004.

7. Oruko, R.O., Selvarajan, R., Ogola, H.J.O., Edokpayi, J.N., Odiyo, J.O., Contemporary and future direction of chromium tanning and management in sub Saharan Africa tanneries, Process Saf Environ Prot, 2020, 133, 369-86, https://doi.org/10.1016/j. psep.2019.11.013.

8. Lock, K., Janssen, C.R., Ecotoxicity of Chromium (III) to Eisenia fetida, Enchytraeus albidus, and Folsomia candida, Ecotoxicol Environ Saf, 2002, 51, 3, 203-5, https://doi.org/10.1006/ eesa.2001.2122.

9. van Gestel, C.A.M., Dirven-van Breemen, E.M., Baerselman, R., Accumulation and elimination of cadmium, chromiumandzinc and effects on growth and reproduction in Eisenia andrei (Oligochaeta, Annelida), Sci Total Environ, 1993, 134, 585-97, https:// doi.org/10.1016/S0048-9697(05)80061-0.

10. OECD, Test No. 207: Earthworm, Acute Toxicity Tests [Internet], 1984, available from: https://www.oecd-ilibrary.org/ content/publication/9789264070042-en

11. EPA, Ecological Effects Test Guidelines OCSPP 850.3100: Earthworm Subchronic Toxicity Test, 2012.

12. Schuldt, M., Testa, H., Reconversion of hop plant residues by vermicomposting. Substrate acceptance on trays and reproductive biology (P5L Test). REDVET - Rev electrón vet - Revista electrónica de Veterinaria [Internet], 2011, 12, 9, available from: https://recyt.fecyt.es/ index.php/REDVET/article/view/14043

13. Domínguez, J., State-of-the-Art and New Perspectives on Vermicomposting Research, in: Earthworm ecology, CRC press; 2004, 401-424, https://doi. org/10.1201/9781420039719.ch20.

14. Barra, J., Marrufo, L., Optimization of Alkaline Hydrolysis of Chrome Shavings to Recover Collagen Hydrolysate and Chromium Hydroxide, Leather and Footwear Journal, 2020, 20, 1, 15-28, https://doi.org/10.24264/Ifj.20.1.2. 
15. Rodríguez, A.R., Marchese, M., Ojea, N., Efecto del Cromo en Eisenia Fetida (Savigny, 1826) (Oligochaeta:

(C) 2020 by the author(s). Published by INCDTPLumbricidae): Toxicidad y Bioacumulación, Natura, 2005, 1, 33, 55-63, https://doi. org/10.14409/natura.v1i33.3791.

ICPI, Bucharest, RO. This is an open access article distributed under the terms and conditions of the Creative Commons Attribution license (http:// creativecommons.org/licenses/by/4.0/). 